ADLFI. Archéologie de la France -

INFORMATIONS

Informations

une revue Gallia

Midi-Pyrénées | 1989

\title{
Canton de Revel
}

\section{OpenEdition \\ Journals}

Édition électronique

URL : http://journals.openedition.org/adlfi/10397

ISSN : 2114-0502

Éditeur

Ministère de la culture

Référence électronique

"Canton de Revel », ADLFI. Archéologie de la France - Informations [En ligne], Midi-Pyrénées, mis en ligne le 01 mars 1997, consulté le 03 mai 2019. URL : http://journals.openedition.org/adlfi/10397

Ce document a été généré automatiquement le 3 mai 2019

(c) Ministère de la Culture et de la Communication, CNRS 


\section{Canton de Revel}

Date de l'opération : 1989 (PR)

Inventeur(s) : Calvet J.-P

1 Les prospections entreprises sur quatre communes ont révélé plusieurs sites inédits: Saint-Félix, La Grange et Cadenac (gisements du I ${ }^{\mathrm{er}}$ s. avant J.-C., avec amphores vinaires italiques Dr. 1) ; Revel, Chemin de la Sabière (établissement gallo-romain) ; Saint-Julien, En Coque (souterrain aménagé de type monocellulaire); Roumens, le Village (dépotoir constitué de céramiques du XVI ${ }^{\mathrm{e}} \mathrm{s}$. et d'ossements humains).

INDEX

Index chronologique : âge du Fer, Antiquité romaine, Temps Modernes operation Prospection (PR) 